\title{
ARTICLE
}

\section{Epidermal micromorphology of floret parts in Aeluropus (Poaceae)}

\author{
Samaneh Mosaferi* and Maryam Keshavarzi \\ Department of Plant Sciences, Faculty of Biological Sciences, Alzahra University, Tehran, Iran
}

\begin{abstract}
Aeluropus from Poaceae comprises 5 species in the world and 3 species in Iran. This halophytic perennial is distributed in salty and dry soils of Asia, Europe, and Africa. In addition to being used as fodder, it can stabilize the soil by its rhizome or stolon. These features make Aeluropus a valuable plant. In this study, lemma and palea of 10 populations of Aeluropus were studied micromorphologically by scanning electron microscope (SEM) to determine diagnostic features among species studied. Eight characters as micro-prickle, macro-hair, long cell outline, cork and silica cells, papilla, salt gland, and epicuticular wax were studied. The occurrence of salt glands and silica cells in populations/taxa studied showed the ability of Aeluropus to tolerate harsh habitats. Our result showed the taxonomic value of floret micromorphological features to separate Aeluropus species.

Acta Biol Szeged 65(1):35-45 (2021)
\end{abstract}

\section{KEY WORDS}

Aeluropus

Aeluropodinae

Chloridoideae

lemma

palea

\section{ARTICLE INFORMATION}

Submitted

26 January 2021

Accepted

18 May 2021

*Corresponding author

E-mail: s.mosaferi@alzahra.ac.ir

\section{Introduction}

Aeluropus Trin. (Poaceae, Chloridoideae) is one of the two genera of subtribe Aeluropodinae with 5 species in the world (The Plant List 2013). Previously it comprised 4 species in Iran (Bor 1970). As A. pungens (M. Bieb.) K. Koch was synonymized to $A$. littoralis (Gouan) Parl., its species reduced to three taxa (The Plant List 2013). Some infra-specific taxa were recorded for this genus in Iran (Khodashenas 2009).

Members of this halophytic weed are distributed in tropical regions of Asia, Europe, and Africa (Zhang et al. 2006). This genus contains rhizomatous or stoloniferous perennials that help the soil stabilization. It has dense capitate, spike like or panicle inflorescence with compressed spikletes, chartaceous unequal glumes which are shorter than lemma, keeled lemma which is glabrous or hairy on margins, palea with ciliate on keel and oblongelliptic or oblong-obovate caryopsis (Bor 1970; Zhang et al. 2006).

Aeluropus is distributed in saline soils, sandy shores and dry regions (Zhang et al. 2006). Members of Poaceae family grown in saline soils, have unicellular or bicellular salt glands as a common adaptive feature (Wahit 2003; Kobayashi 2008; Céccoli et al. 2015). All Poaceae subfamilies have micro-hairs except Pooideae (Amarasinghe and Watson 1988, 1989; Kobayashi 2008) but functional salt glands are only observed in Chloridoideae (Bell and
Ó Leary 2003; Kobayashi et al. 2007; Hameed et al. 2013). This subfamily is adapted to harsh and saline environments by having salt gland (Taleisnik and Anton 1988; Columbus et al. 2007; Peterson et al. 2010).

The importance of micromorphological characters in Poaceae has been established by different authors. Different vegetative and reproductive parts as leaf (Mavi et al. 2011; Ortúňez and Cano-Ruiz 2013), glume (Klimko and Wysakowska 2015), lemma (Acedo and Llamas 2001; Li et al. 2010, Ortúňez and Cano-Ruiz 2013; Harms and Mendenhall 2015), palea (Klimko et al. 2009; Ortúňez and De La Fuente 2010), and caryopsis (Terrell and Peterson 1993; Gandhi et al. 2013, Zhang et al. 2014; Liu et al. 2015) have been studied micromorphologically to solve taxonomic problems at different levels in Poaceae.

Lemma and palea epidermal characters are of taxonomic value in identifying and studying relationship between genera and species in Chloridoideae (Liu et al. 2010). There are limited studies on the micromorphology of Aeluropus species. Liu et al. (2010) studied lemma and palea characters in A. littoralis. Features as long cell outline, cork cell, micro-hair, macro-hair, papillae, microprickle and silica body have been used to characterize this taxon from other members of Chloridoideae.

This study aims to describe micromorphological characters of lemma and palea in Aeluropus species in Iran and to discuss taxonomic value of these features at interspecific level. 
Table 1. Voucher details of population studied.

\begin{tabular}{|c|c|c|c|c|c|c|}
\hline Species & No. & Locality & Longitude & Latitude & Altitude (m) & Voucher No. \\
\hline \multirow{4}{*}{$\begin{array}{l}\text { A. littoralis (Gouan) } \\
\text { Parl. }\end{array}$} & 1 & Kerman, Kahnooj & $28^{\circ} 01^{\prime} 15^{\prime \prime}$ & $57^{\circ} 43^{\prime} 33^{\prime \prime}$ & 531 & 99 a ALUH \\
\hline & 2 & Sistan and Baluchestan, Hirmand, Bar-Ahuyi & $31^{\circ} 06^{\prime} 46^{\prime \prime}$ & $61^{\circ} 47^{\prime} 01^{\prime \prime}$ & 481 & ha-169 ALUH \\
\hline & 3 & East Azerbaijan, Tabriz to Ahar, Talkheh Rud & $38^{\circ} 01^{\prime} 55^{\prime \prime}$ & $46^{\circ} 56^{\prime} 58^{\prime \prime}$ & 1635 & $8511 \mathrm{ALUH}$ \\
\hline & 4 & Tehran, Saveh & $35^{\circ} 01^{\prime} 17^{\prime \prime}$ & $50^{\circ} 21^{\prime} 24^{\prime \prime}$ & 998 & $8512 \mathrm{ALUH}$ \\
\hline \multirow{4}{*}{$\begin{array}{l}\text { A. lagopoides (L.) } \\
\text { Thwaites }\end{array}$} & 5 & Semnan, Garmsar & $35^{\circ} 13^{\prime} 06^{\prime \prime}$ & $52^{\circ} 20^{\prime} 27^{\prime \prime}$ & 850 & 8513 ALUH \\
\hline & 6 & Kerman, Jazmourian, Zeh-e-kalut & $27^{\circ} 48^{\prime} 15^{\prime \prime}$ & $58^{\circ} 36^{\prime} 11^{\prime \prime}$ & 392 & 99 b ALUH \\
\hline & 7 & Sistan and Baluchestan, Hirmand, Bar-Ahuyi & $31^{\circ} 06^{\prime} 46^{\prime \prime}$ & $61^{\circ} 47^{\prime} 01^{\prime \prime}$ & 481 & ha-168 ALUH \\
\hline & 8 & Fars, Maharlu lake & $29^{\circ} 26^{\prime} 05^{\prime \prime}$ & $52^{\circ} 46^{\prime} 38^{\prime \prime}$ & 1461 & 66947 ALUH \\
\hline \multirow{2}{*}{$\begin{array}{l}\text { A. macrostachyus } \\
\text { Hack. }\end{array}$} & 9 & Kerman, Kahnooj & $28^{\circ} 01^{\prime} 15^{\prime \prime}$ & $57^{\circ} 43^{\prime} 33^{\prime \prime}$ & 531 & $851 \mathrm{ALUH}$ \\
\hline & 10 & Sistan and Baluchestan, $20 \mathrm{~km}$ of Mirjaveh to Jaleq & $27^{\circ} 35^{\prime} 33^{\prime \prime}$ & $62^{\circ} 41^{\prime} 28^{\prime \prime}$ & 849 & 49878 IRAN \\
\hline
\end{tabular}

\section{Materials and Methods}

To study the micromorphological features, 10 accessions of 3 species of Aeluropus were considered. Samples were obtained from specimens at Alzahra University Herbarium (ALUH) and Herbarium of Iranian Research Institute of Plant Protection, Department of Botany (IRAN). They were identified using taxonomic literatures such as Flora Iranica (Bor 1970), Flora of Iraq (Bor 1968) and Flora of Turkey (Davis 1985). Voucher specimens and localities are mentioned in Table 1.

For lemma and palea studies, mature florets of spikelets, were chosen and complete lemmas and paleas were separated. Middle part of abaxial surfaces were examined without any treatment. At first, each part was examined by Olympus stereomicroscope and Dino Lite digital microscope. Then samples were mounted on metallic stubs, coated with gold in a sputter coater with 100 A layer of gold and examined and photographed with Hitachi SU3500 scanning electron microscope (SEM). Eight diagnostic characters of lemma and palea were evaluated (Tables 2 and 3). Terminology was adapted from Snow (1996), Acedo and Llamas (2001), Mejía-Saules and Bisby (2003) and Liu et al. (2010) for lemma and palea characters. Barthlott et al. (1998) terminology was used for epicuticular wax variation.

Table 2. Micro-morphological characters of lemma surfaces in populations/taxa studied.

\begin{tabular}{|c|c|c|c|c|c|c|c|c|c|}
\hline \multirow[t]{2}{*}{ Species } & \multirow[t]{2}{*}{ Pop. no. } & \multicolumn{8}{|c|}{ Characters } \\
\hline & & Micro-prickle & Macro-hair & $\begin{array}{l}\text { Long cell } \\
\text { out line }\end{array}$ & Cork cell & Silica cell & Papillae & $\begin{array}{l}\text { Bicellular micro- } \\
\text { hair }\end{array}$ & Epicuticular wax \\
\hline \multirow{4}{*}{ A. littoralis } & 1 & a-type & absent & $\begin{array}{l}\text { wide U- } \\
\text { shaped }\end{array}$ & absent & $\begin{array}{l}\text { dumbbell- } \\
\text { shaped }\end{array}$ & on long cell & long base-cell & granule, platelet \\
\hline & 2 & $\begin{array}{l}\text { a-type, } \\
\text { b-type }\end{array}$ & papilla-base & $\begin{array}{l}\text { wide U- } \\
\text { shaped }\end{array}$ & oblong & $\begin{array}{l}\text { dumbbell- } \\
\text { shaped }\end{array}$ & $\begin{array}{l}\text { on long and } \\
\text { short cells }\end{array}$ & long base-cell & platelet, granule \\
\hline & 3 & absent & absent & straight & oblong & $\begin{array}{l}\text { cross- } \\
\text { shaped }\end{array}$ & $\begin{array}{l}\text { on long and } \\
\text { short cells }\end{array}$ & long base-cell & platelet, granule \\
\hline & 4 & a-type & absent & straight & absent & $\begin{array}{l}\text { dumbbell- } \\
\text { shaped }\end{array}$ & $\begin{array}{l}\text { on long and } \\
\text { short cells }\end{array}$ & short base-cell & granule, platelet \\
\hline \multirow{4}{*}{ A. lagopoides } & 5 & absent & $\begin{array}{l}\text { geniculate, } \\
\text { papilla-base }\end{array}$ & $\begin{array}{l}\text { wide U- } \\
\text { shaped }\end{array}$ & absent & $\begin{array}{l}\text { dumbbell- } \\
\text { shaped }\end{array}$ & on long cell & $\begin{array}{l}\text { long and short } \\
\text { base-cell }\end{array}$ & granule \\
\hline & 6 & $\begin{array}{l}\text { a-type, } \\
\text { b-type }\end{array}$ & absent & $\begin{array}{l}\text { wide U- } \\
\text { shaped }\end{array}$ & squared & $\begin{array}{l}\text { dumbbell- } \\
\text { shaped }\end{array}$ & $\begin{array}{l}\text { on long and } \\
\text { short cells }\end{array}$ & $\begin{array}{l}\text { long and short } \\
\text { base-cell }\end{array}$ & cube, granule \\
\hline & 7 & absent & geniculate & straight & absent & $\begin{array}{l}\text { dumbbell- } \\
\text { shaped }\end{array}$ & $\begin{array}{l}\text { on long and } \\
\text { short cells }\end{array}$ & $\begin{array}{l}\text { long and short } \\
\text { base-cell }\end{array}$ & granule, platelet \\
\hline & 8 & absent & papilla-base & $\begin{array}{l}\text { wide U- } \\
\text { shaped }\end{array}$ & absent & $\begin{array}{l}\text { dumbbell- } \\
\text { shaped }\end{array}$ & $\begin{array}{l}\text { on long and } \\
\text { short cells }\end{array}$ & long base-cell & platelet \\
\hline \multirow{2}{*}{$\begin{array}{l}\text { A. macro- } \\
\text { stachyus }\end{array}$} & 9 & absent & geniculate & $\Omega$-shaped & oblong & $\begin{array}{l}\text { dumbbell- } \\
\text { shaped }\end{array}$ & $\begin{array}{l}\text { on long and } \\
\text { short cells }\end{array}$ & long base-cell & granule \\
\hline & 10 & a-type & geniculate & $\Omega$-shaped & absent & $\begin{array}{l}\text { dumbbell- } \\
\text { shaped }\end{array}$ & $\begin{array}{l}\text { on long and } \\
\text { short cells }\end{array}$ & long base-cell & granule, platelet \\
\hline
\end{tabular}


Table 3. Micro-morphological characters of palea surfaces in populations/taxa studied.

\begin{tabular}{|c|c|c|c|c|c|c|c|c|c|}
\hline \multirow[t]{2}{*}{ Species } & \multirow[t]{2}{*}{ Pop. no. } & \multicolumn{8}{|c|}{ Characters } \\
\hline & & Micro-prickle & Macro-hair & $\begin{array}{l}\text { Long cell } \\
\text { out line }\end{array}$ & Cork cell & Silica cell & Papillae & $\begin{array}{l}\text { Bicellular micro- } \\
\text { hair }\end{array}$ & Epicuticular wax \\
\hline \multirow{4}{*}{ A. littoralis } & 1 & b-type & absent & $\Omega$-shaped & absent & \multicolumn{2}{|c|}{ cross- shaped on long cell } & absent & cube, granule \\
\hline & 2 & a-type, b-type & geniculate & $\Omega$-shaped & absent & \multicolumn{2}{|c|}{ cross- shapedabsent } & absent & platelet, granule \\
\hline & 3 & a-type, b-type & absent & $\Omega$-shaped & oblong & absent & absent & short base-cell & granule, platelet \\
\hline & 4 & absent & absent & $\Omega$-shaped & $\begin{array}{l}\text { crescent- } \\
\text { shaped }\end{array}$ & \multicolumn{2}{|c|}{ cross- shaped on long cell } & absent & platelet, granule \\
\hline \multirow{4}{*}{ A. lagopoides } & 5 & absent & absent & $\begin{array}{l}\text { wide U- } \\
\text { shaped }\end{array}$ & $\begin{array}{l}\text { crescent- } \\
\text { shaped }\end{array}$ & absent & absent & absent & granule \\
\hline & 6 & a-type & absent & $\Omega$-shaped & $\begin{array}{l}\text { scalariform, } \\
\text { oblong }\end{array}$ & absent & on long cell & short base-cell & granule \\
\hline & 7 & absent & absent & $\begin{array}{l}\text { wide U- } \\
\text { shaped }\end{array}$ & oblong & absent & absent & absent & platelet, granule \\
\hline & 8 & c- type & absent & $\begin{array}{l}\text { wide U- } \\
\text { shaped }\end{array}$ & $\begin{array}{l}\text { oblong, cres- } \\
\text { cent-shaped }\end{array}$ & absent & absent & absent & platelet \\
\hline \multirow{2}{*}{$\begin{array}{l}\text { A. macro- } \\
\text { stachyus }\end{array}$} & 9 & b-type, c-type & absent & $\Omega$-shaped & absent & $\begin{array}{l}\text { saddle- } \\
\text { shaped }\end{array}$ & absent & absent & cube, granule \\
\hline & 10 & a-type & absent & $\Omega$-shaped & absent & \multicolumn{2}{|c|}{ cross- shaped on long cell } & absent & granule \\
\hline
\end{tabular}

\section{Results}

\section{Lemma micromorphology}

Lemma micromorphological details of each population are summarized in Table 2. Outline of long cell in intercostal areas were straight to wide $\mathrm{U}$-shaped in A. littoralis and $A$. lagopoides and $\Omega$-shaped in A. macrostachyus (Figs. $1-3)$. Short cells were found in species studied. Cork cells were absent in most populations studied. Cork cells were only observed in Bar-Ahuyi and Talkheh Rud population of $A$. littoralis (Figs. 1B-C). Zeh-e-kalut population of $A$. lagopoides showed square cork cells (Fig. 2b). Three other populations did not have cork cells.

In A. macrostachyus, Kahnooj population had small oblong cork cell. They were frequent in costal zones with dense distribution (Fig. 3a).

Dumbbell-shaped silica cells were found in all taxa. In Talkheh Rud population of A. littoralis, cross-shaped silica cells were determined. This population had the densest distribution of silica cells among other populations of $A$. littoralis (Fig. 1c). The density of silica cells in A. macrostachyus was the highest among species studied (Fig. 3).

Papillae occurred on long and short cells of lemma surface in populations/taxa studied. They were only observed on long cells in Kahnooj population of A. littoralis (Fig. 1A) and Garmsar population of A. lagopoides (Fig. 2A).

Macro-hairs showed variation in length and density. These unicellular structures were densely covered the lemma surface of A. lagopoides (especially in Garmsar population) (Fig. 2A) while in A. macrostachyus they were sparse. In A. macrostachyus, geniculate macro-hairs were seen (Fig. 3) while in A. lagopoides, two types of macrohairs, geniculate and papilla- base, were seen (Fig. 2). Except Bar-Ahuyi population, there was no macro-hair in A. littoralis populations (Fig. 1).

In lemma and palea, three types of micro-prickles were observed: barbs developed from the apex of the base with direct point (a- type), barbs with direct point not developed from the base (b-type) and barbs with recurved point not developed from the apex of the base (c-type) (adapted from Ellis 1979). Micro-prickles were commonly found in A. littoralis lemma surface (Fig. 1) but in two other taxa, these features were sparse.

Salt glands were observed in all taxa studied. These bicellular excretory organs were commonly found in coastal areas of lemma epidermis. Taxa studied showed chloridoid type of bicellular micro-hairs. This type of micro-hair was classified to two sub-types: short-base cell and long-cell base. A. macrostachyus had long-cell base type (Fig. 3) but A. littoralis and A. lagopoides had both types (Figs. 1-2).

Epicuticular wax showed differences in type and distribution among taxa/population studied. In A. littoralis, platelet and granule waxes were seen in populations. These waxes were densely covered the lemma surface of Saveh population (Fig. 1D-d). Among populations of $A$. lagopoides, Garmsar population showed the densest cover of granular wax (Fig. 2a). Zeh-e-kalut population showed sparse distribution of cube and granule wax. Other populations showed medium coverage of platelet and granule 

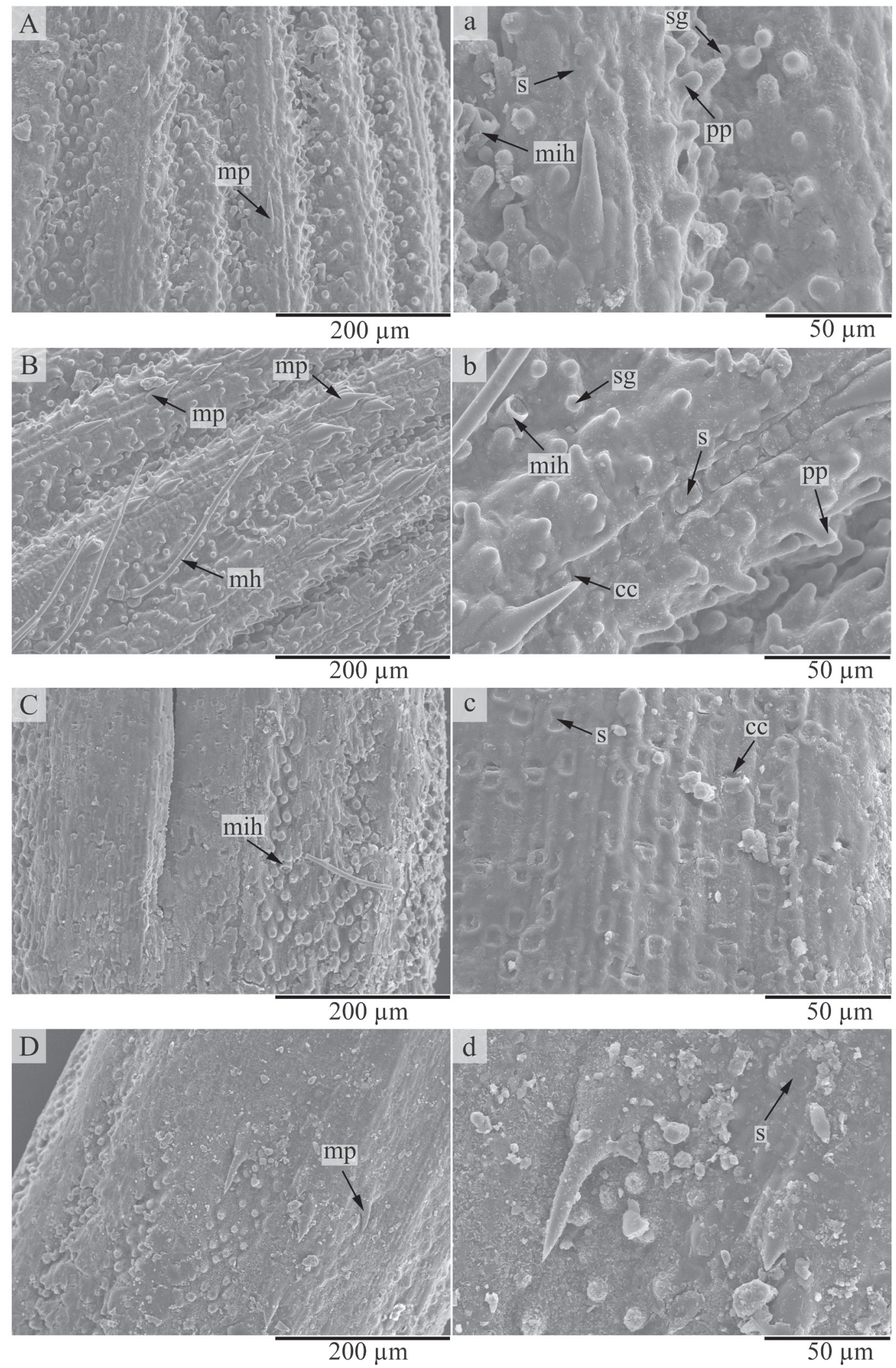

Figure 1. SEM micrographs of lemma surfaces in A. littoralis. A-a: Kahnooj; B-b: Bar-Ahuyi; C-c: Talkheh Rud; D-d: Saveh. cc: cork cell; s: silica cell; mh: macro-hair; mih: micro-hair; mp: micro-pickle; pp: papillae; sg: salt gland. 


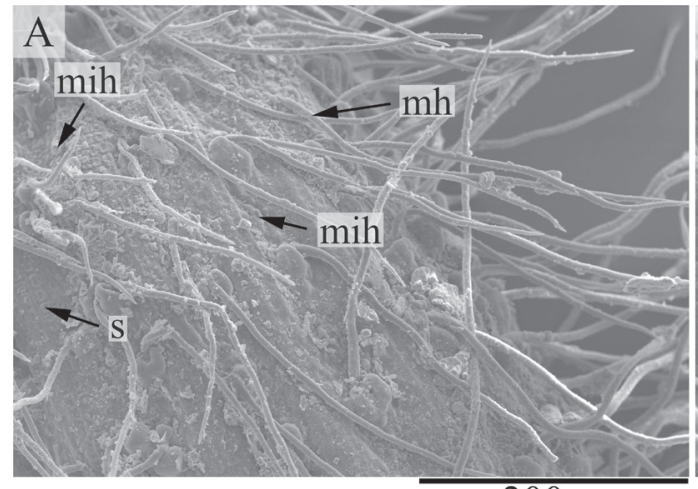

$200 \mu \mathrm{m}$

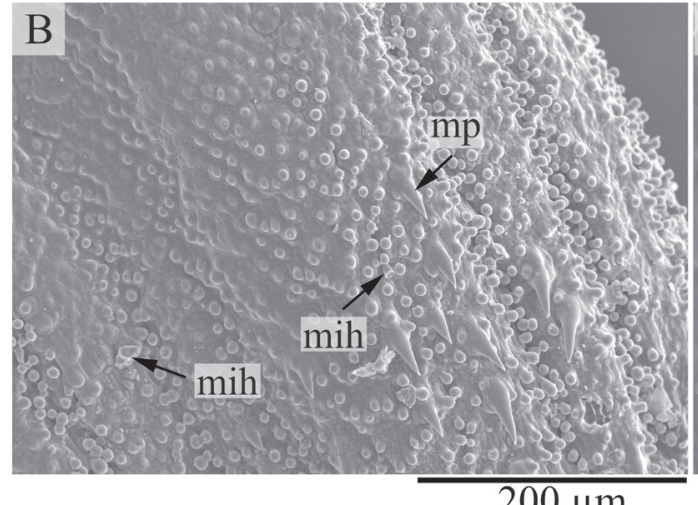

$200 \mu \mathrm{m}$

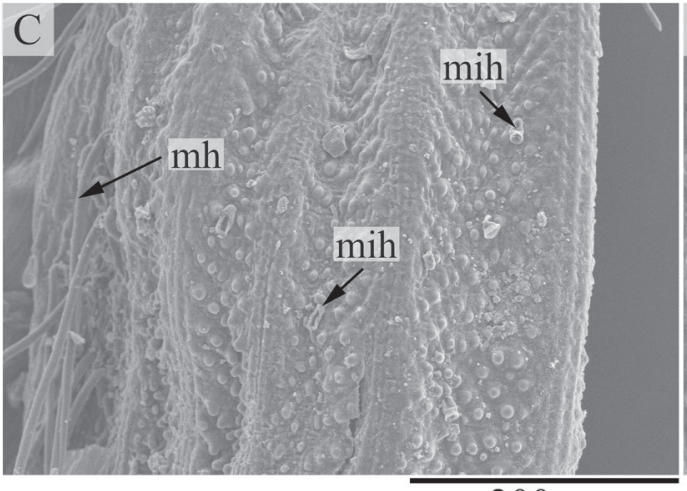

$200 \mu \mathrm{m}$

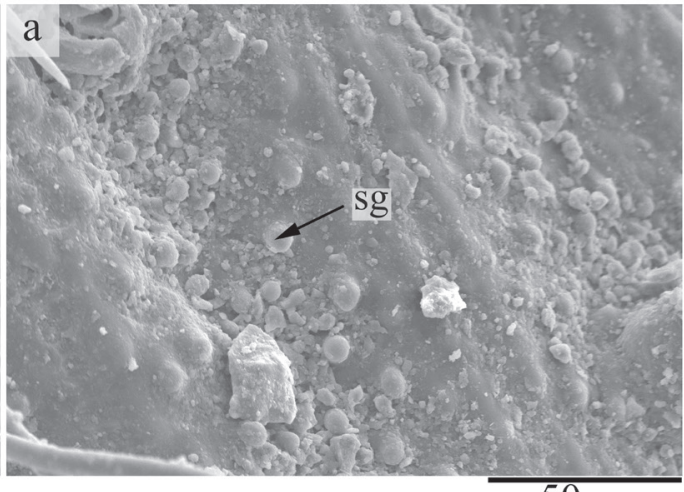

$50 \mu \mathrm{m}$
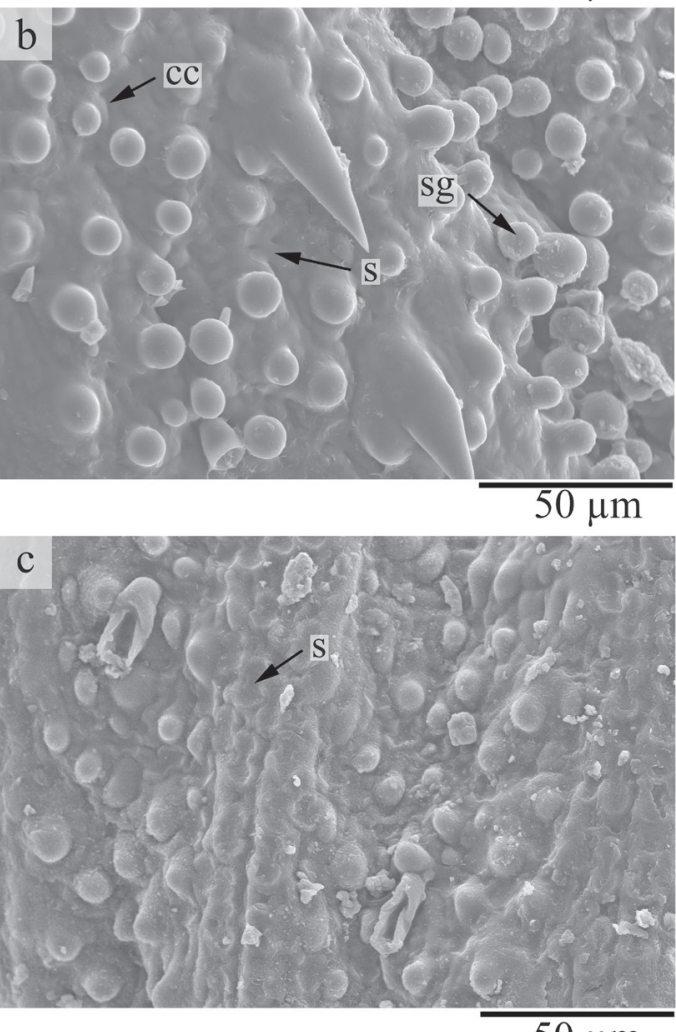

$50 \mu \mathrm{m}$
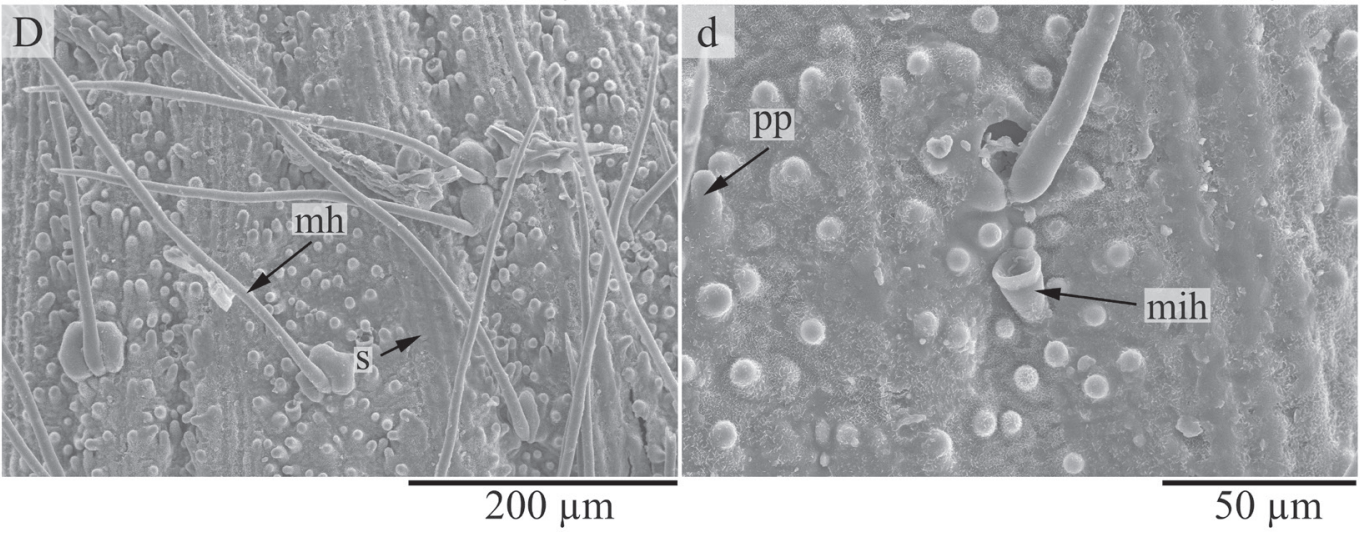

Figure 2. SEM micrographs of lemma surfaces in A. lagopoides. A-a: Garmsar; B-b: Zeh-e-kalut; C-c: Bar-Ahuyi; D-d: Maharlu lake. cc: cork cell; s: silica cell; mh: macro-hair; mih: micro-hair; mp: micro-pickle; pp: papillae; sg: salt gland. 

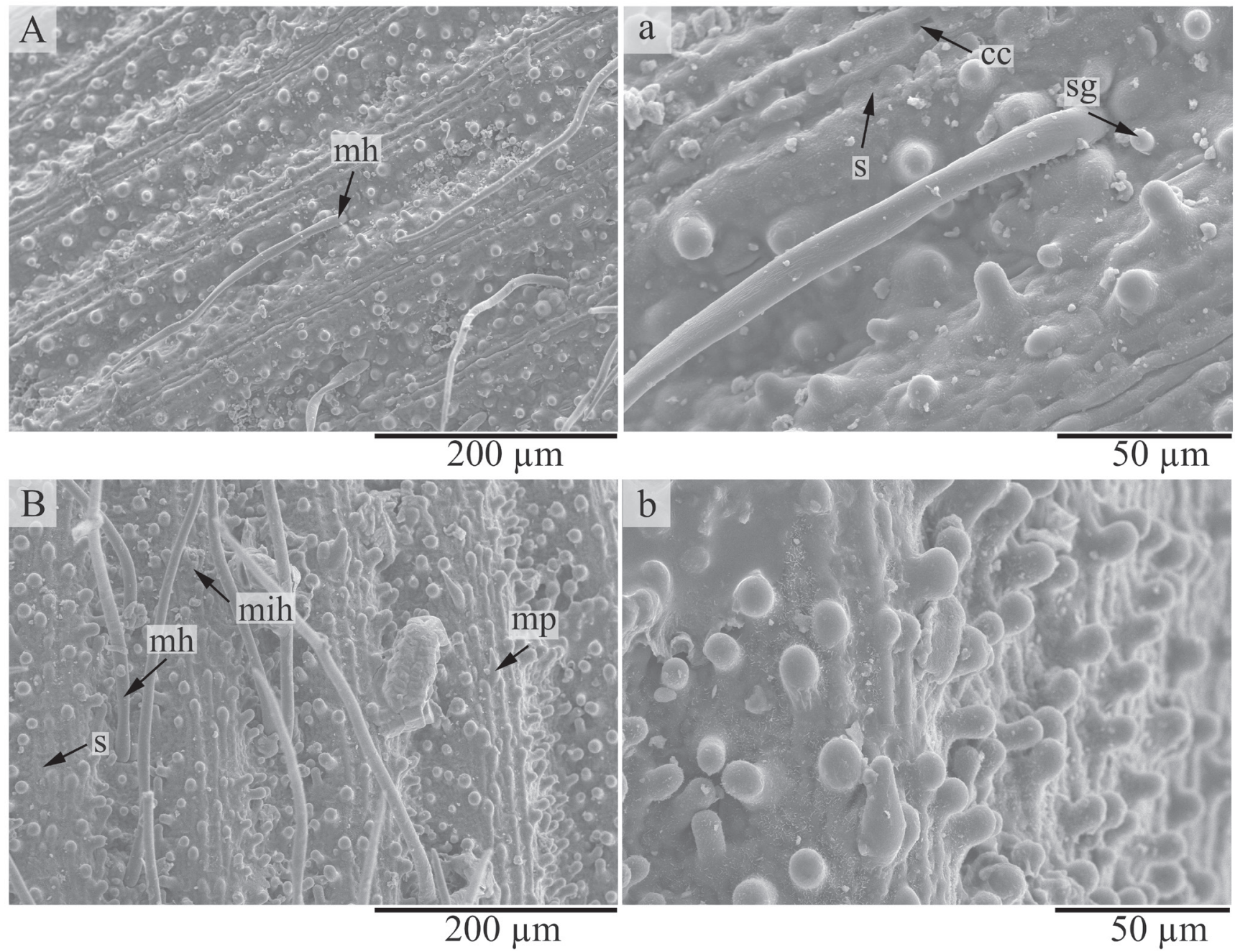

Figure 3. SEM micrographs of lemma surfaces in A. macrostachyus. A-a: Kahnooj; B-b: Mirjaveh to Jaleq. cc: cork cell; s: silica cell; mh: macro-hair; mih: micro-hair; mp: micro-pickle; sg: salt gland.

wax types (Fig. 2). Lemma surface of A. macrostachyus was sparsely covered with granule and platelet waxes (Fig. 3).

\section{Palea micromorphology}

A. littoralis and A. macrostachyus showed $\Omega$-shaped outline in long cells (Figs. 4, 5E-F) while A. lagopoides showed wide U-shaped in long cells outline except Zehe-kalut population (Fig. 5A-D) (Table 3). A. littoralis and A. lagopoides showed cork cells in some populations. A. littoralis had oblong and crescent- shaped cork cells (Fig. 4D) but populations of $A$. lagopoides showed modifications in shape of cork cells (Fig. 5A-D). Cork cells were not observed in A. macrostachyus (Fig. 5E-F). Silica cells were only observed in A. littoralis and A. macrostachyus. Two populations of $A$. macrostachyus had saddle- shaped and cross- shaped silica cells (Fig. 5E-F) while in A. littoralis only cross-shaped ones were found (Fig. 4). Bar-Ahuyi population of $A$. littoralis had the densest distribution of silica cells and Kahnooj population of A. macrostachyus had the sparest.

Papillae were found on long cells of four populations studied. Macro-hairs were lacking in species studied except Bar-Ahuyi population of A. littoralis (not shown). In $A$. littoralis, all populations had micro-prickles except Saveh population. In A. lagopoides, only Maharlu lake and Zeh-e-kalut populations had micro-prickles. Bar-Ahuyi population of $A$. littoralis and Maharlu lake population of A. lagopoides showed more micro-prickles among other populations mostly distributed in the margin (not shown).

Chloridoid type of bicellular micro-hairs were only present in Talkheh Rud population of A. littoralis (Fig. 4C) and Zeh-e-kalut population of A. lagopoides (not shown). These two populations showed short-base cell chloridoid type. 

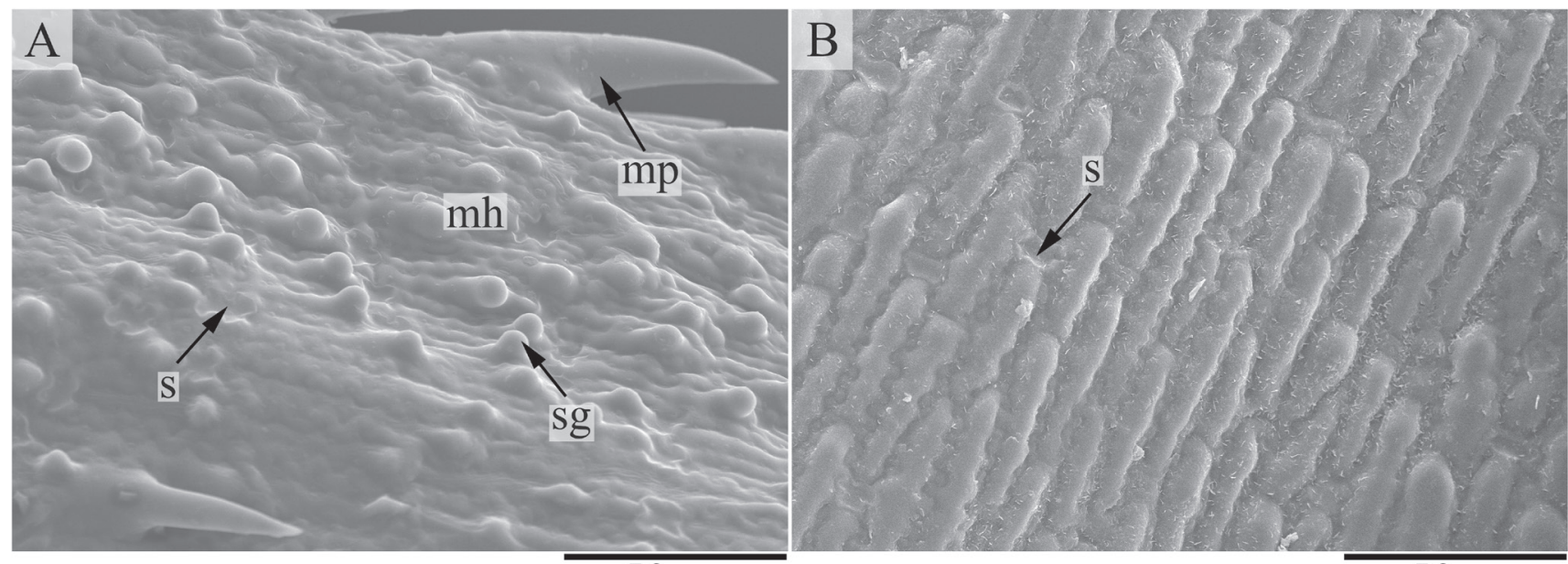

$50 \mu \mathrm{m}$
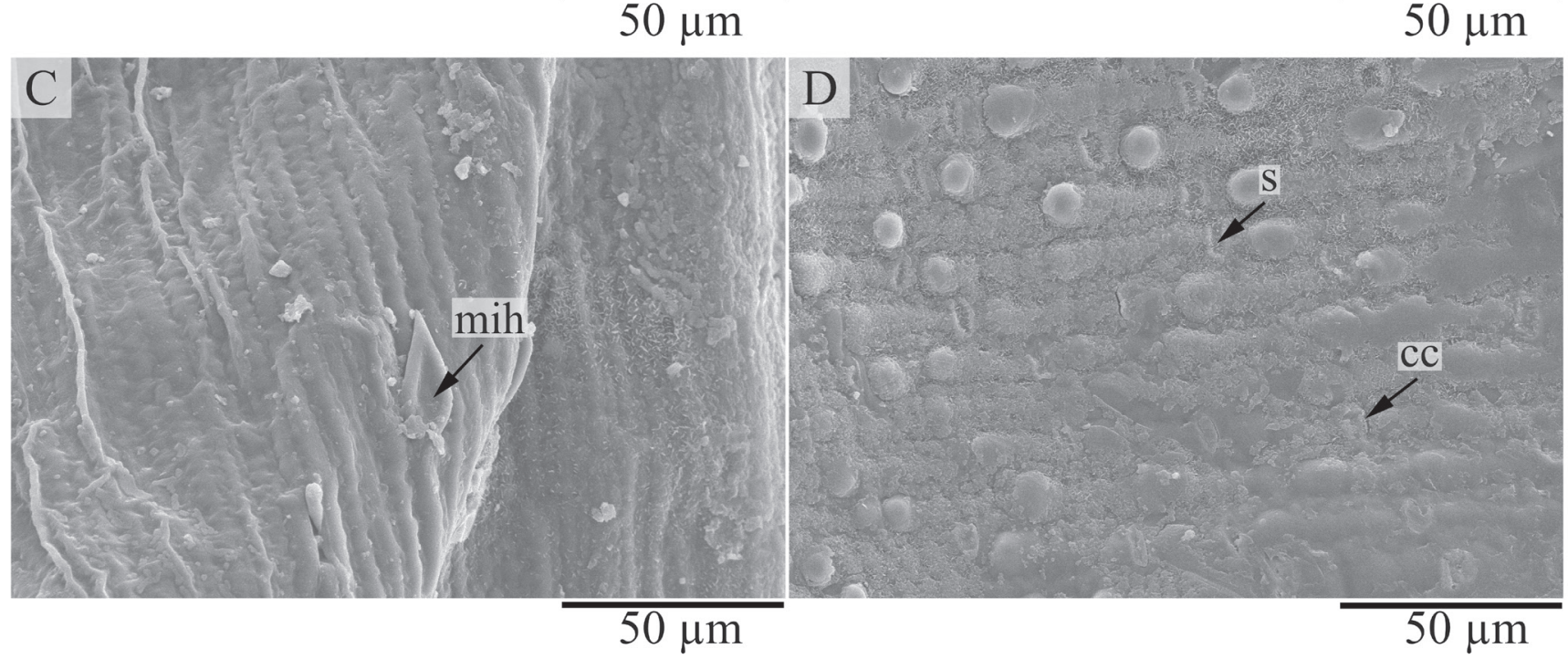

Figure 4. SEM micrographs of palea surfaces in A. littoralis. A: Kahnooj, B: Bar-Ahuyi, C: Talkheh Rud, D: Saveh. cc: cork cell, s: silica cell, mih: micro-hair; mp: micro-pickle, sg: salt gland.

Dense platelet waxes covered palea surface of Saveh population in A. littoralis. A little number of granules were also seen in this population (Fig. 4D). Platelet and granular waxes were irregularly distributed in palea surfaces of Bar-Ahyui and Talkheh Rud populations (Fig. 4B-C). Wax was scarce in Kahnooj population. In populations of A. lagopoides, granule and platelet waxes were seen with dense distribution except Zeh-e-kalut population (Fig. 5A-D). In A. macrostachyus wax was rare (Fig. 5E-F).

\section{Discussion}

Aeluropus is a halophyte plant distributed in dry and saline regions of different parts of Iran (Bor 1970). This grass showed dumbbell-shaped, cross-shaped and saddle-shaped silica cells in lemma and palea surfaces of nearly all popu- lations studied. These features enable Aeluropus to live in water deficiency (Santi et al. 2018). In addition, Chloridoid type of salt glands in the form of long base-cells and short base-cells microhairs were scattered in the different parts of Aeluropus accessions that enable them to tolerate high salinity (Kobayashi 2008; Céccoli et al. 2015). We found epicuticular wax in shapes of cube, granule, and platelet with different density on the lemma and palea surfaces showing adaptation in different conditions.

The natural occurrence of this plant in saline habitats makes it a useful candidate for stabilizing the soil. Moreover, this plant can be used as forage especially in salty and dry soils where little fodders can grow (Zhang et al. 2006; Barzegargolchini et al. 2017).

In this study, the highest level of silica body occurred in lemma surface of A. macrostachyus. Presence of more silica cells cause less grazing (Quigley and Anderson 

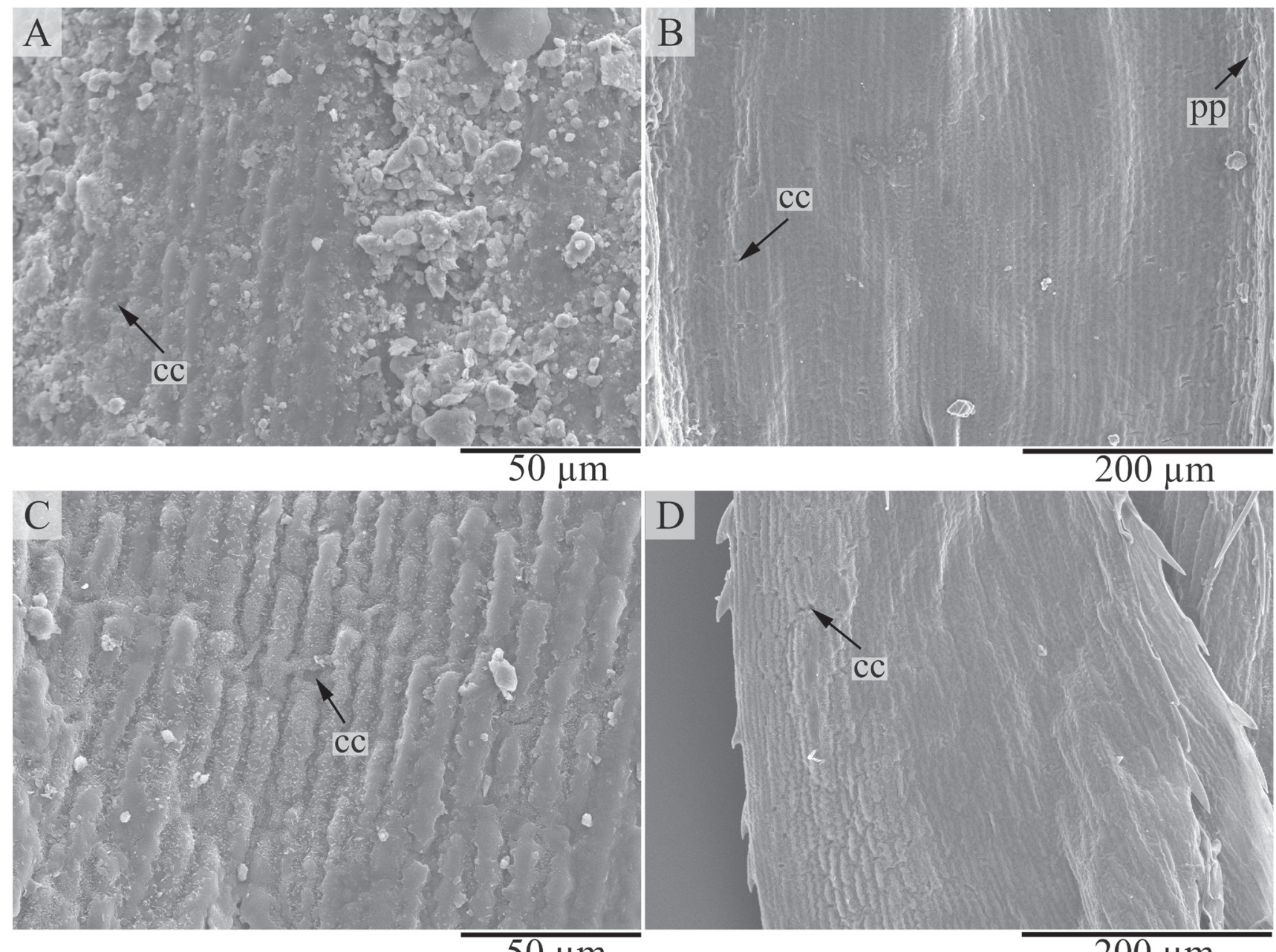

$200 \mu \mathrm{m}$
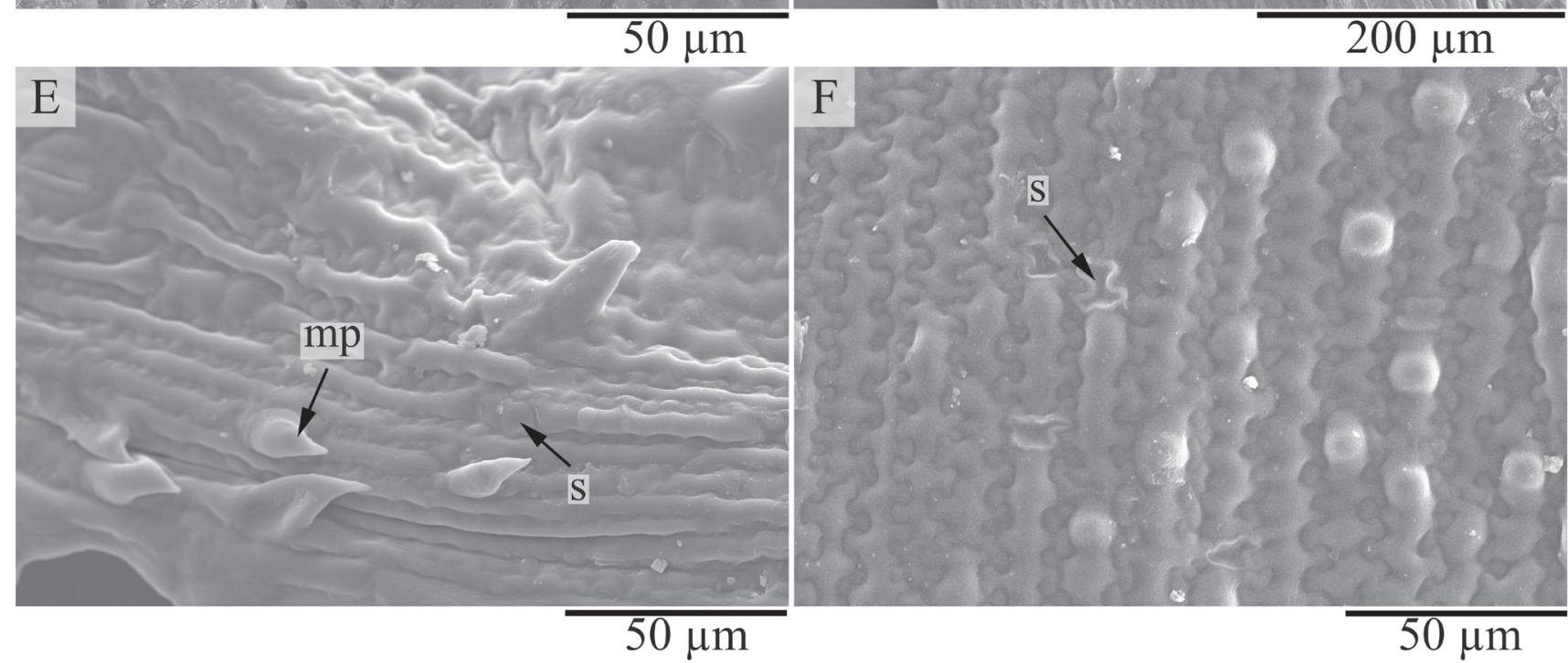

Figure 5. SEM micrographs of palea surfaces in A. lagopoides. A: Garmsar, B: Zeh-e-kalut, C: Bar-Ahuyi, D: Maharlu lake; E-F: A. macrostachyus; E: Kahnooj; F: Mirjaveh to Jaleq. cc: cork cell; s: silica cell; mp: micro-pickle; pp: papillae. 


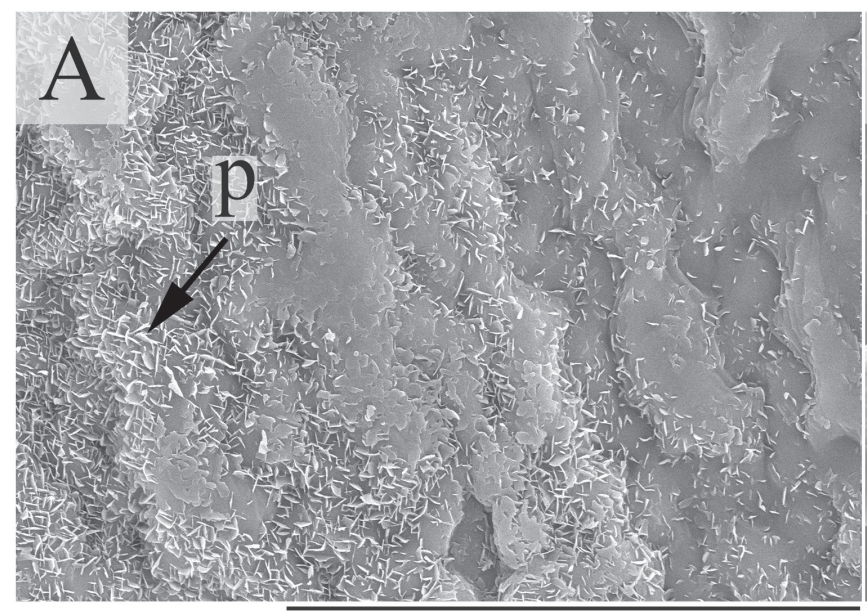

$20 \mu \mathrm{m}$

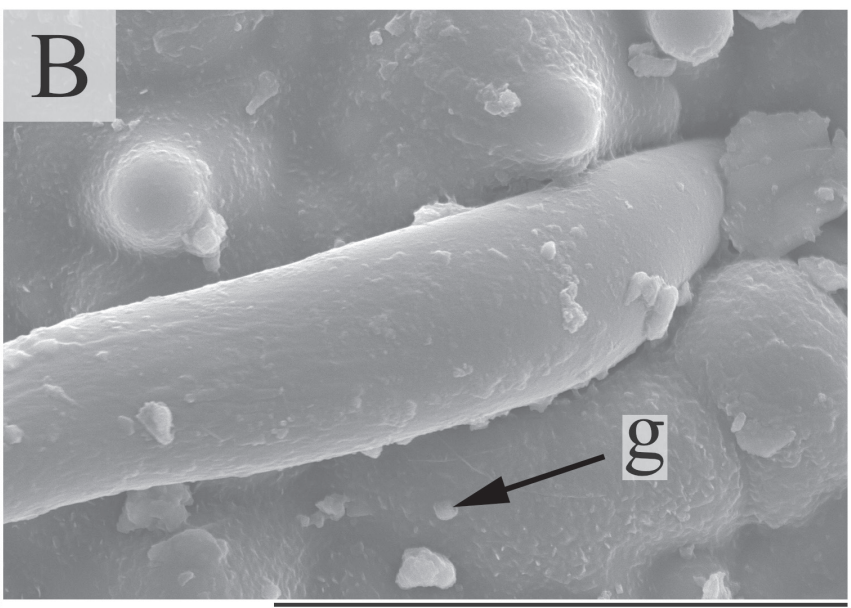

$20 \mu \mathrm{m}$

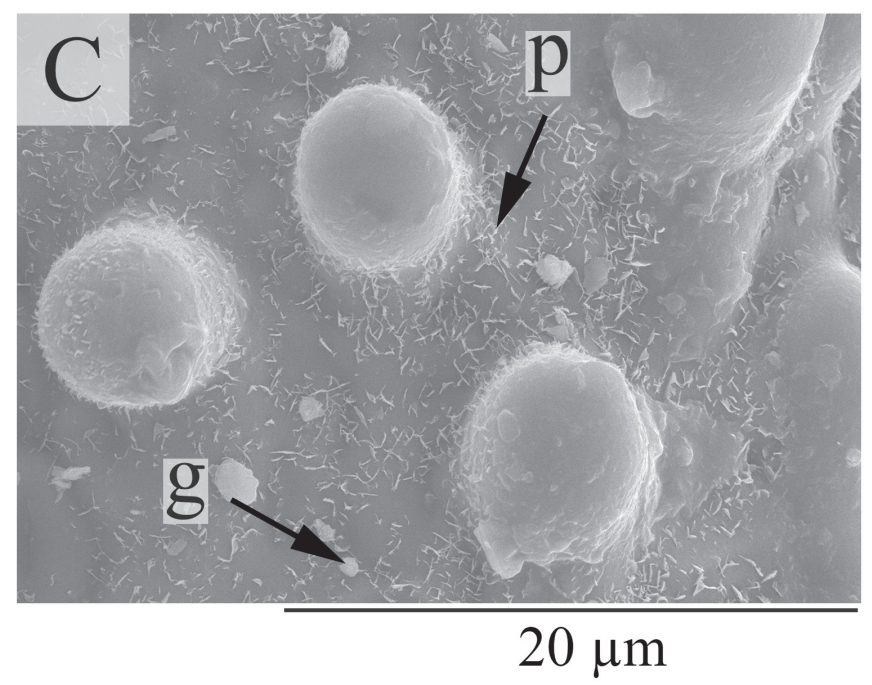

Figure 6. SEM micrographs of lemma and palea surfaces. A: platelet waxes in lemma surface of $A$. lagopoides (Maharlu lake population); B: granule waxes in lemma surface of $A$. macrostachyus (Mirjaveh to Jaleq population); C: platelet and granule waxes in palea surface of $A$. littoralis (Saveh population). p: platelet wax; g: granule wax.

2014). It maybe because of this, foraging quality of two palatable taxa, $A$. littoralis and $A$. lagopoides were studied more by different authors (Abbasi et al. 2002; Sharifi Rad et al. 2013).

All species possessed papillae, silica cells and salt glands on lemma surfaces. Except four populations (no. 2, 3, 6, 9 ), we did not find cork cells on lemma surfaces. Despite palea, papilla-base and geniculate macro-hairs occurred in lemma surface of most populations.

The results of our study suggest that lemma and palea micromorphology may be useful to distinguish Aeluropus species. Although some characters as shape of silica cells in lemma and absence of macro-hairs in palea were uniform among taxa studied, some others differed among species. For example, A. macrostachyus was the only species with
$\Omega$-shaped outline in long cells of lemma and with no salt gland on palea surface. Our results confirmed its distinct position based on morphological characters as Abivardi et al. (2010) mentioned before. Liu et al. (2010) noted to U-shaped outline for long cells and dumbbell shape for silica cells in lemma of $A$. littoralis. Our results were in agreement with them. Despite some overlapping features, generally our micro-morphological results separate the three species studied.

\section{Acknowledgement}

We are grateful to the curator of Herbarium of Iranian Research Institute of Plant Protection, Department of 
Botany (Iran) for permission to access Aeluropus specimens.

\section{References}

Abbasi F, Khavarinethad RA, Kouchaki A, Fahimi H (2002) Effect of salinity on growth and physiological aspects of Aeluropus littoralis. Desert 7:101-110.

Abivardi F, Keshavarzi M, Assadi M, Seifali M (2010) Numerical taxonomy of Aeluropus Trin. species (Poaceae) in Iran. TBJ 2:85-102.

Acedo C, Llamas F (2001) Variation of micromorphological characters of lemma and palea in the genus Bromus (Poaceae). Ann Bot Fenn 38:1-14.

Amarasinghe V, Watson L (1988) Comparative ultrastructure of microhairs in grasses. Bot J Linn Soc 98:303-319.

Amarasinghe V, Watson L (1989) Variation in salt secretory activity of microhairs in grasses. Aust J Plant Physiol 16:219-229.

Barthlott W, Neinhuis Ch, Cutler D, Ditsch F, Meusel I, Theisen I, Wilhelmi H (1998) Classification and terminology of plant epicuticular waxes. Bot J Linn Soc 126:237-260.

Barzegargolchini B, Movafeghi A, Dehestani A, Mehrabanjoubani P (2017) Morphological and anatomical changes in stems of Aeluropus littoralis under salt stress. JPMB 5:40-48.

Bell HL, Ó Leary JW (2003) Effects of salinity on growth and cation accumulation of Sporobolus virginicus. Am J Bot 90:1416-1424.

Bor NL (1968) Aeluropus Trin. In Townsend CE, Guest ER, Al-Rawi A, Eds., Flora of Iraq, Vol. 9. Iraq Ministry of Agriculture, Baghdad, 420-425.

Bor NL (1970) Aeluropus Trin. In Rechinger KH, Ed., Flora Iranica, Vol. 70. Akad. Druck- und Verlagsanstalt, Graz, 419-423.

Céccoli G, Ramos J, Pilatti V, Dellaferrera I, Tivano JC, Taleisnik E, Vegetti AC (2015) Salt glands in the Poaceae family and their relationship to salinity tolerance. Bot Rev 81:162-178.

Columbus JT, Cerros-Tlatilpa R, Kinney MS, SiqueirosDelgado ME, Bell HL, Griffith MP, Refulio-Rodriguez NF (2007) Phylogenetics of Chloridoideae (Gramineae): a preliminary study based on nuclear ribosomal internal transcribed spacer and chloroplast trnL-F sequences. Aliso 23:565-579.

Davis PH (1985) Aeluropus Trin. In Davis PH, Guner A, Eds., Flora of Turkey and the east Aegean Islands, Vol. 9. Edinburgh University Press, Edinburgh, 569-572.

Ellis RP (1979) A procedure for standardizing comparative leaf anatomy in the Poaceae. II. The epidermis as seen in surface view. Bothalia 12:641-671.
Gandhi D, Alberts S, Pandya N (2013) Morphometric analysis of caryopsis in some species of Eragrostis (Poaceae). Telopea 15:87-97.

Hameed M, Ashraf M, Naz N, Nawaz T, Batool R, Ahmad MS, Ahamd F, Hussain M (2013) Anatomical adaptations of Cynodon dactylon (L.) Pers. from the salt range (Pakistan) to salinity stress. II. leaf anatomy. Pak J Bot 43:133-142.

Harms RT, Mendenhall J (2015) Taxonomic utility of lemma micromorphological characters in the Sporobolus compositus and Sporobolus vaginiflorus complexes (Poaceae). Lundellia 18:1-9.

Khodashenas M (2009) Two new records and a new combination of the genus Aeluropus (Poaceae) for the flora of Iran. IJB 15:61-62.

Klimko M, Pudelska H, Wojciechowska B, Klimko W (2009) Variation of micromorphological characters of lemma and palea in Aegilops kotschyi and Aegilops biuncialis $\times$ Secale cereal hybrids, amphiploids and parental forms. Steciana 13:167-176.

Klimko M, Wysakowska I (2015) Epidermal features of glumes and florets in Aegilops geniculata Roth and Aegilops peregrina (Hack.) Maire et Weiller $\times$ Secale cereal L. hybrids, amphiploids and parental forms. Steciana 19:13-24.

Kobayashi H (2008) Ion secretion via salt glands in Poaceae. JJPS 2:1-8.

Kobayashi H, Masaoka Y, Takahashi Y, Ide Y, Sato S (2007) Ability of salt glands in Rhodes grass (Chloris gayana Kunth) to secrete $\mathrm{Na}^{+}$and $\mathrm{K}^{+}$. Soil Sci Plant Nutr 53:764771.

Liu H, Hu XY, Liu YX, Liu Q (2015) Caryopsis micromorphological survey of Sorghum (Poaceae) - Taxonomic implications. S Afr J Bot 99:1-11.

Liu Q, Zhang DX, Peterson PM (2010) Lemma micromorphological characters in the Chloridoideae (Poaceae) optimized on a molecular phylogeny. S Afr J Bot 76:196-209.

Mavi DÖ, Doğan M, Cabi E (2011) Comparative leaf anatomy of the genus Hordeum L. (Poaceae). Turk J Bot 35:357-368.

Mejía-Saules F, Bisby FA (2003) Silica bodies and hooked papillae in lemmas Melica species (Gramineae: Pooideae). Bot J Linn Soc 141:447-463.

Ortúňez E, Cano-Ruiz J (2013) Epidermal micromorphology of the genus Festuca L. subgenus Festuca (Poaceae). Plant Syst Evol 299:1471-1483.

Ortúňez E, De La Fuente V (2010) Epidermal micromorphology of the genus Festuca L. (Poaceae) in the Iberian Peninsula. Plant Syst Evol 284:201-218.

Peterson PM, Romaschenko K, Johnson G (2010) A classification of the Chloridoideae (Poaceae) based on multi-gene phylogenetic trees. Mol Phylogenet Evol 55:580-598.

Quigley KM, Anderson TM (2014) Leaf silica concentration in Serengeti grasses increases with watering but not clipping. insights from a common garden study and 
literature review. Front Plant Sci 5:1-10.

Santi LP, Haris N, Mulyanto D (2018) Effect of bio-silica on drought tolerance in plants. 2018. IOP conference series: Earth and Environmental Science 183(012014):1-8.

Sharifi Rad M, Sharifi Rad J, Teixeira Da Silva JA, Mohsenzadeh S (2013) Forage quality of two halophytic species, Aeluropus lagopoides and Aeluropus littoralis, in two phenological stages. IJAPP 4:998-1005.

Snow N (1996) The phylogenetic utility of lemmatal micromorphology in Leptochloa s.l. and related genera in subtribe Eleusininae (Poaceae, Chloridoideae, Eragrostideae). Ann Missouri Bot Gard 83:504-529.

Taleisnik EL, Anton AM (1988) Salt glands in Pappophorum (Poaceae). Ann Bot 62:383-388.

Terrell EE, Peterson PM (1993) Caryopsis morphology and classification in the Triticeae (Pooideae: Poaceae). Smithson Contrib Bot 83:1-25.
The Plant List (2013) Version 1.1. http://www.theplantlist. org/ (Accessed 01.01.2013).

Wahit A (2003) Physiological significance of morpho-anatomical features of halophytes with particular reference to Cholistan Flora. Int J Agric Biol 5:207-212.

Zhang MSH, Chen SH, Philips SM (2006) Aeluropus Trin. In Zhengyi W, Raven PH, Deyuan H, Eds., Flora of China, Vol. 22. 458-459. http://www.efloras.org/flora_page. aspx?flora_id=2. (Accessed 22.02.2008).

Zhang Y, Hu X, Liu Y, Liu Q (2014) Caryopsis micromorphological survey of the genus Themeda (Poaceae) and allied spathaceous genera in the Andropogoneae. Turk J Bot 38:665-676. 
